\title{
Donor Information
}

National Cancer Institute

\section{Source}

National Cancer Institute. Donor Information. NCI Thesaurus. Code C158611.

Information about the donor. 